\title{
Notice of elections to the Country Councils of the British Dental Association
}

Nominations are sought for election to:

- English Council

- Northern Ireland Council

- Scottish Council

- Welsh Council.

Councils have the following remit:

- To provide regular advice and comment to the Principal Executive Committee as a consultative committee

- To consider and advise the Principal Executive Committee on all matters relating to dentistry within their country

- To advise the Principal Executive Committee on all aspects of policy within their country, facilitating external expert and member input to policy formation where required

- To receive regular reports from the Principal Executive Committee, to enable the Council to debate and comment on the activities of the Principal Executive Committee

- To liaise with branches and sections

- Elected members of country councils will be called upon to form an Interim Principal Executive Committee, if the Principal Executive Committee resigns, is dissolved, or becomes inquorate. This means they temporarily take responsibility as Directors of the Association and direction of the Association as a trade union in these circumstances, until fresh elections are completed.

The Country Councils play a vital role in ensuring that the Principal Executive Committee, which is concerned with the strategic direction and governance of the Association, is kept in touch with the views and concerns of members. Country Council members are the 'voice of members' to the Principal Executive Committee and senior management team.

The Country Councils together constitute the United Kingdom Council which, amongst other functions, considers an annual report from the Principal Executive Committee on its strategic priorities and activities.

\section{Term of office}

Successful candidates will assume their places in early 2022. They will then serve for three years with the entitlement to stand for a further three-year term of office at that point.

More information about this and other BDA elections can be found at the BDA elections website www.bda.org/elections.

Nomination forms must be submitted online by $\mathbf{1 7 . 0 0}$ Monday 25 October 2021. A link to the online nomination portal can be found at www.bda.org/elections.

For more information about the elections to the Councils or the role of a Council member please contact the BDA's Election Manager Stephen Skelton on 02075634141 or stephen.skelton@ bda.org. 